Original Research Article

\title{
Evaluation of fermentation potential of wild and UV-mutated yeasts screened from traditional murcha.
}

\author{
Jeny Subba ', Basanta Kumar Rai ${ }^{2}$, Dil Kumar Limbu'2, Sangen Ruma Rai ${ }^{l}$
}

'Dharan Multiple Campus, Dharan, Nepal

${ }^{2}$ Central Campus of Technology, Tribhuvan University, Hattisar, Dharan, Nepal

*Corresponding author: Department of Food Technology, Central Campus of Technology, Tribhuvan University, Hattisar, Dharan, Nepal, E-mail: basanta_64@yahoo.com

\begin{abstract}
:
Murcha (an amylolytic starter) from different parts of Eastern Nepal were screened for fermentative yeasts. The most potential one was UV-mutated ( $8 \mathrm{~W}$ lamp at $\lambda=254 \mathrm{~nm}$ and an intensity of $44.21 \mathrm{Wm}^{-2}$ for $5-50 \mathrm{~s}$ ) to study the effect of mutation on growth and fermentation properties. Respiratory-deficient mutants (RDMs) that resulted from the mutation were identified by triphenyl tetrazolium chloride (TTC) overlay technique and replica-plated for further isolation. Cell growth, substrate utilization, and ethanol yield of the mutants were compared with normal cells by carrying out fermentation in high-test cane molasses broth of $30^{\circ} \mathrm{Bx}$. An exhaustive screening of the samples resulted in only two murcha viz., from Laxmimarga (LM) and Udayapur (UD), having the desirable fermentation properties. UV-mutation study of UD and LM yeasts (both identified as strains of Saccharomyces cerevisiae) showed $8-12 \%$ survival and $\sim 22 \%$ RDMs yield of the survived cells. Out of the 8 randomly selected RDMs, only UDm4 (colony No. 4 from UD) showed fermentation properties worth further investigation. Comparison of UD, LM and UDm4 by fermenting molasses (high test) broth of $30^{\circ} \mathrm{Bx}$ showed the least growth of UDm 4 but the highest alcohol yield ( $9 \%$ and $16 \%$ more compared to UD and LM, respectively). The present finding indicates that it is possible to improve fermentation properties of feral yeasts from murcha by relatively simple UVmutation approach. Finding the right mutant (the selective screening part), however, may involve considerable time and effort.
\end{abstract}

Keywords: Feral yeast, murcha, respiratory deficient mutants

\section{Introduction}

Murcha, an amylolytic starter cake used for cereal-based alcoholic fermentations, harbors feral fermentative yeasts, amylolytic molds and lactic acid bacteria as the essential organisms (KC et al, 1999; Lee, 1999; Subba, 2016). The isolation and study of brewing/fermentation potential of murcha yeasts have been carried out by several workers, including KC et al. (1999), Rai and Subba (2004), and Rai (2006) but work on improvement aspects of the isolates has largely been ignored. Literatures on protocols for the improvement of yeast strains abound (Bridges, 1976; Bacila et al, 1978; Chambers et al, 2009; Reed and Nagodawithana, 1991; Walker, 1998; Smith and Burke, 2014; Steensels et al, 2014) but these generally deal with only 'culture' or laboratory yeast species, polyploid/anueploid Saccharomyces cerevisiae in particular. Wild yeasts have not been used so far for the study. Of the several improvement methods described, UV-mutation is the simplest, most rapid, and requires minimal laboratory facilities (Bridges, 1976). This approach for producing respiratory deficient mutants (RDMs) has recently been reviewed by several workers and its possibility for improving brewing potential of yeasts has been conclusively proved (Bacilla et al, 1978; McCann and Barnett, 1984; Hammond, 2003). However, research on the improvement of strains of feral yeasts in general, and murcha yeasts in particular, is almost non-existent. Since UV-mutation is the simplest (yet very powerful) technique of strain improvement strategies (Bridges, 1976), this approach can be an attractive proposition for preliminary studies on improving the fermentation potential of murcha yeasts. 


\section{Materials and Methods}

Murcha cakes were collected from different parts of Eastern Nepal. Screening of the potential fermentative yeasts was carried out following the protocol developed by Rai and Subba (2016). Characterization of the yeast species was done by auxanography (sugar assimilationand fermentation tests) (Harrigan and McCance, 1976; Payne et al, 1998; Kurtzman et al, 2003).

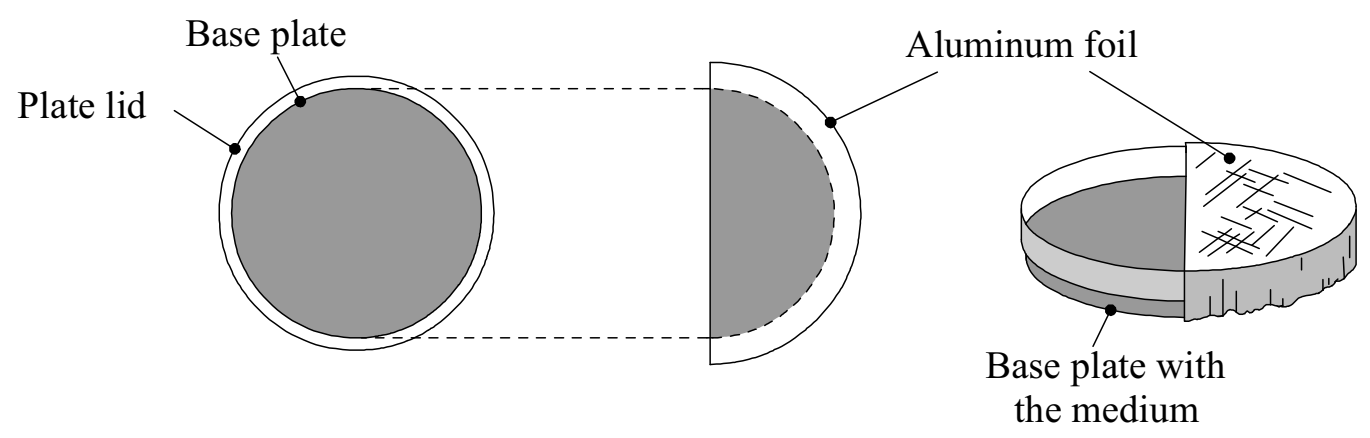

Fig 1. Wrapping of the spread-plated base plate with Al foil

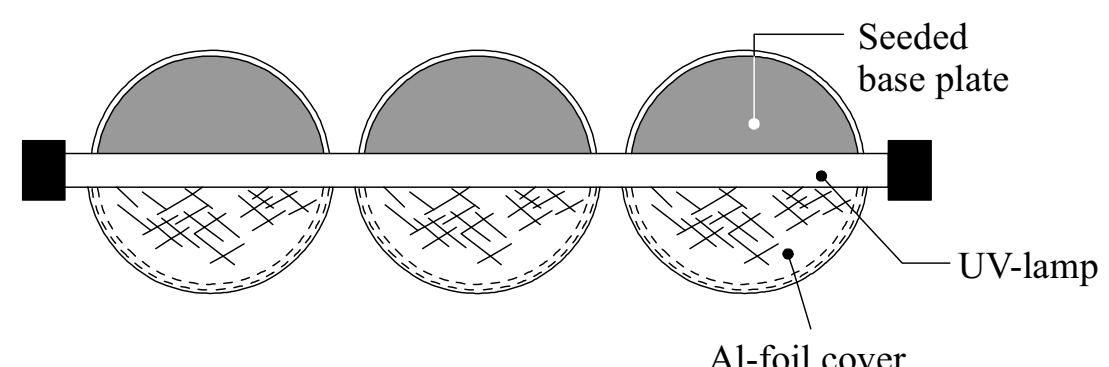

Fig 2. Arrangement of seeded plates for UV irradiation

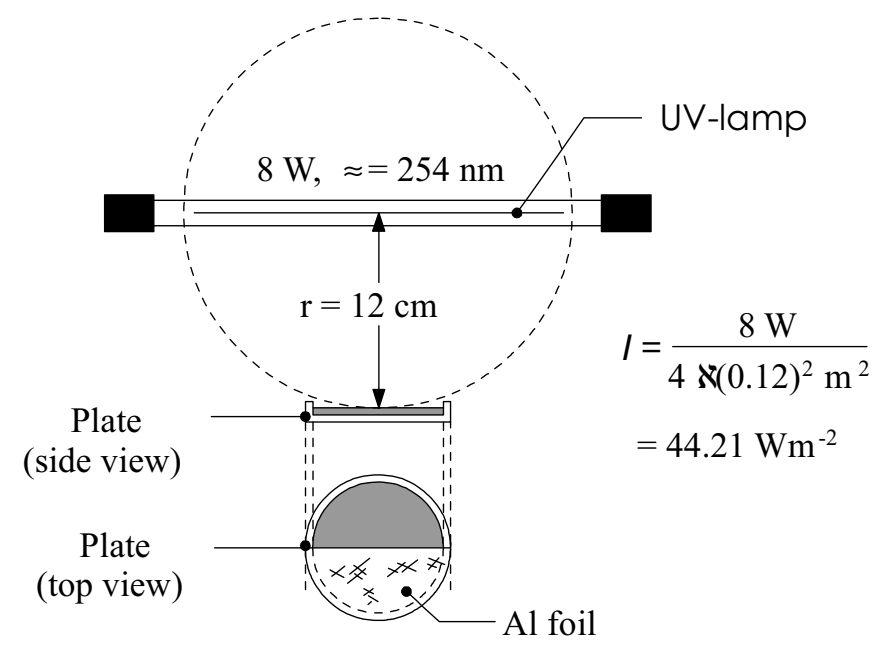

Fig 3. Exposure of seeded plate to UV irradiation

Briefly, the method involved enrichment of fermentative yeast cells (in murcha) by fermenting 15\% high-test cane molasses solution ( $\mathrm{pH} 4.0$ with citric acid) for 15 days to ensure the profuse (and selective) growth of yeast cells, microscopic examination (negative staining), spreadplating on molasses agar, stock culture preparation (molasses agar slants), and auxanography. UV-mutation study was based on the protocols described by Markert (1953), Winston (2008), D'Costa and Santoro (2009), and Rai and Subba (2016). Briefly, the isolates were washed twice by suspending the cells in distilled water and centrifuging at $3000 \mathrm{rpm}$ for $5 \mathrm{~min}$, diluting in distilled 
water to give 20-30 cells $/ \mathrm{mL}$, and spread-plating $(\sim 0.1$ $\mathrm{mL}$ ) on molasses agar. Mutation was carried out in UV cabinet (Labtronics ${ }^{\circledR}$, India). For this, the seeded plates were exposed to UV radiation ( $8 \mathrm{~W}$ lamp at $\lambda=254 \mathrm{~nm}$ and an intensity of $44.21 \mathrm{Wm}^{-2}$ for $5-50 \mathrm{~s}$, at $5 \mathrm{~s}$ interval) (Fig. 1 - Fig. 3), immediately incubated in dark at $30{ }^{\circ} \mathrm{C}$ for $24 \mathrm{~h}$, and survival rates observed. Plates with survival rates of 10-15\% (von Borstel and Mehta, 1976) were selected and RDM cells screened by replica-plating and TTC $\left(\right.$ Merck $\left.^{\circledR}\right)$-overlay method (Boulton and Quain, 2001; White and Zainasheff, 2010). Finally, 8 randomly selected mutant colonies were compared with normal cells for fermentation kinetics (cell growth and substrate utilization) in high-test cane molasses medium of 30 Brix ( $\mathrm{pH} 4.0$ with citric acid). Fermentation was carried out in $1000-\mathrm{mL}$ bottle with a working volume of $750 \mathrm{~mL}$ and the pitching rate of $10^{6}$ cells $/ \mathrm{mL} /$ Brix (Rai, 2012). Substrate concentration at $30^{\circ}$ Brix was selected to test the hardiness of the yeast as this sugar concentration is taken as the practical limit for fermentation by Saccharomyces cerevisiae (Reed, 1987). Cell growth was determined during the fermentation by modified direct microscopic count (DMC) (Rai and Subba, 2016).

Substrate utilization was determined by measuring drop in total soluble solids (TSS) ( ${ }^{0}$ Brix) with a portable refractometer $\left(\right.$ Hanna $^{\circledR}$ make, \pm 0.01 unit) for a fermentation period of 12 days under ambient temperature $\left(28-30{ }^{\circ} \mathrm{C}\right)$. Due consideration was also given to the findings of Atala et al. (2001), McKay et al, (2011), and Felix et al, (2014) on alcoholic fermentation. Alcohol contents of the final broths were also determined employing the routine pycnometric method (Rai and Subba, 2016).

\section{Results and Discussion}

\section{Screening of fermentative yeasts}

All of the murcha samples (a total of 8) were found to have different fermentation vigor, as inferred by the rate of drop in TSS. Only two murcha samples, viz., from Udayapur (UD) and Laxmimarga (LM) were considered worth further investigation. Both the murcha types were found to harbor strains of Saccharomyces cerevisiae as confirmed by auxanography (Harrigan and McCance, 1976; Kurtzman et al., 2003). The result agrees with the earlier report (Rai, 2006) that brewing potential of murcha varies a lot (due to variation in microflora composition.

\section{Survival curve}

The survival curves of UV-irradiated cells originating from UD and LM are shown in Fig. 4. The effect of UV-

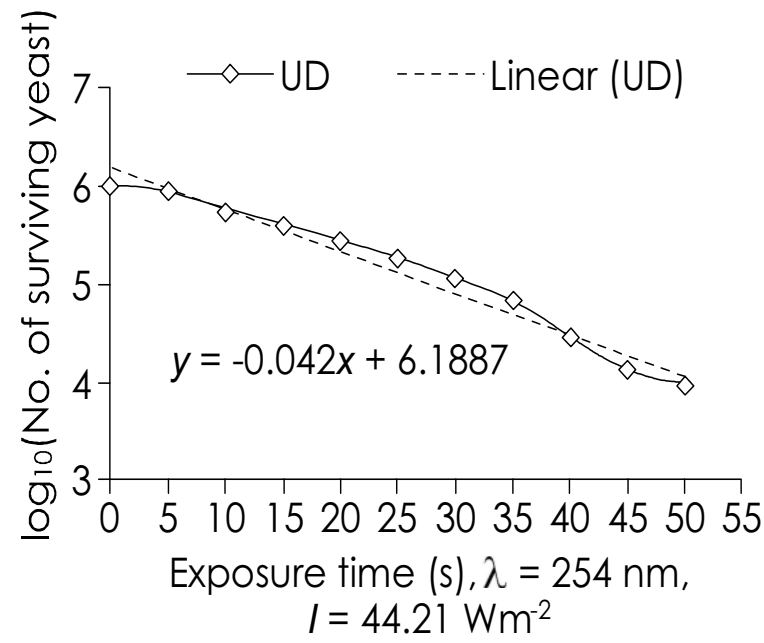

radiation on microbial cells can be expressed in two ways, viz., in terms of (i) \% survival, and (ii) the D-value (time required for the surviving population to be reduced by $1 \log$ cycle) but the former is more common (D'Costa and Santoro, 2009) because the objective of UV-mutation is to get the largest number of mutants with the least possible cell death, rather than to get the highest kill.

From Fig. 4, the slopes of survival curves for UD and LM are 0.0424 and 0.0414 , respectively. The $\mathrm{D}$-values $\left(\mathrm{D}_{44.21}\right.$ $\mathrm{Wm}^{-2}$ ) for UD and LM are therefore $23.58 \mathrm{~s}$ and $24.15 \mathrm{~s}$. von Borstel and Mehta (1976) recommend that the mutant search be carried out at a $10 \%$ survival rate. From Figure 4, this approximates to $25 \mathrm{~s}$ of UV-exposure at an intensity of $44.21 \mathrm{Wm}^{-2}$. In the present work, the survival rates for the said condition were found to be $12 \%$ for Udayapur yeast and $8 \%$ for Laxmimarga yeast.

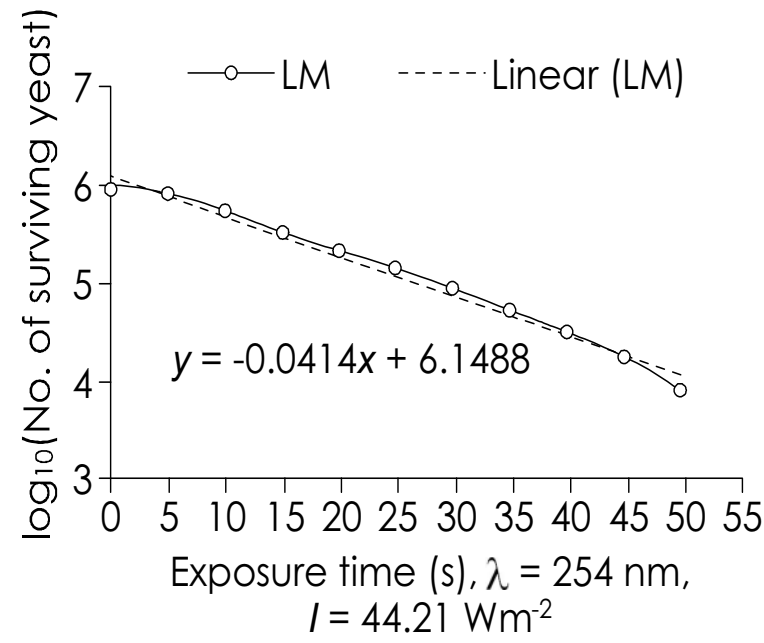

Fig 4. Survival curve of UD and LM yeasts after UV-treatment 


\section{Mutation rate}

$17 \%$ RDMs for Udayapur- and Laxmimarga yeast, Mutation rate, obtained by simple averaging of mutant respectively (Figure 5).

cells in replica plates (TTC overlayed), showed $26 \%$ and
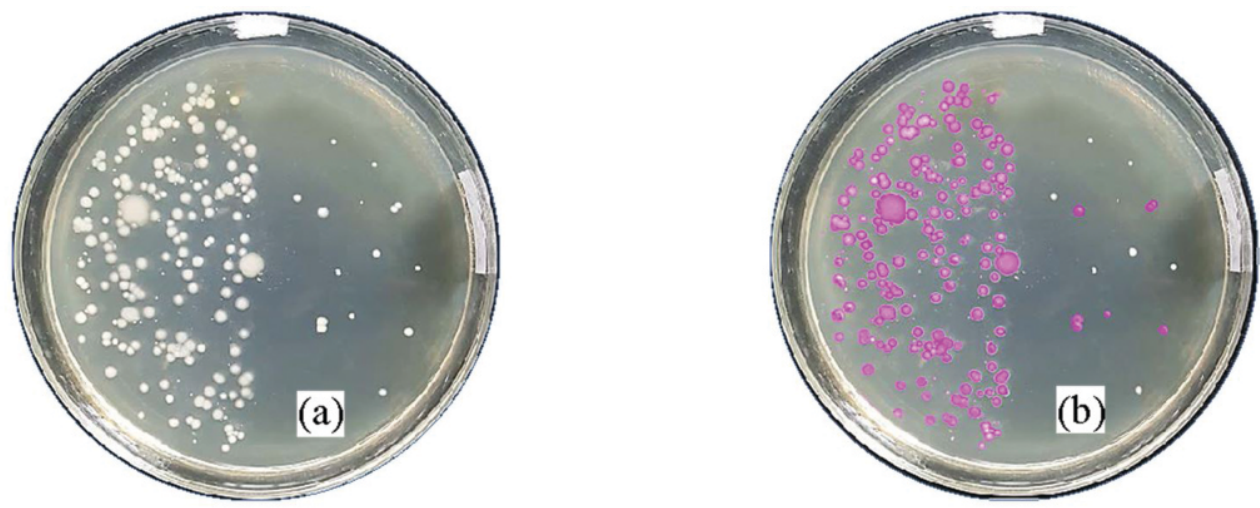

Fig 5. TTC overlay test for the presence of RDMs. (a) before TTC overlay and (b) after TTC overlay

The left-halves of the plates in Figure 5 are control were either poor or very weak fermenters.

colonies (not exposed to UV radiation) and the sparsely populated right-halves of the plates are the surviving colonies. In (b), pink colonies represent healthy cells (respiratory-sufficient) whereas white colonies represent yea RDMs.

\section{Substrate utilization}

Comparison of substrate utilization pattern growth of the yeast isolates LM, UD and UDm 4 is shown as a compound plot in Fig. 6. From the graph, the TSS curves appear to Test fermentation of 8 randomly selected RDM isolates, 4 stabilize after about 6-8 days of fermentation, under the each from UD (coded as UDm1 to UDm4) and LM (coded fermentation conditions employed (pitching rate, as $\mathrm{LMm} 1$ to $\mathrm{LMm} 4)$ in molasses broth $\left(15^{\circ} \mathrm{Brix}, \mathrm{pH} 4.0\right)$ temperature, substrate concentration, initial $\left.\mathrm{pH}\right)$, which is for 12 days at $28-30{ }^{\circ} \mathrm{C}$ showed UDm4 as having the most in agreement with earlier reports of alcoholic rapid fermentation rate and was thus selected for the fermentations (Atala et al, 2001; McKay et al, 2011; Felix comparative kinetic study. The rest of the RDMs isolates etal,2014).

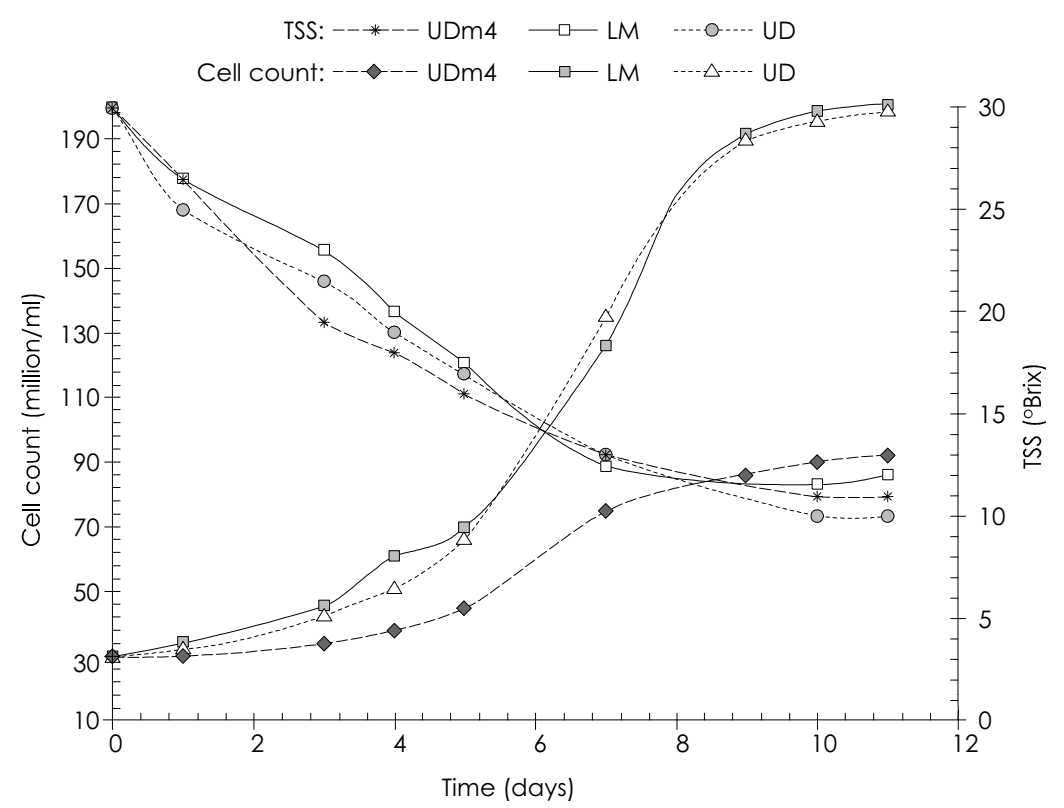

Fig 6. Growth- and substrate utilization kinetics of LM (Laxmimarga yeast), UD (Udayapur yeast) and UDm4 (UDderived RDM isolate No. 4$)$ in molasses broth $\left(30^{\circ}\right.$ Brix $)$ 


\section{Changes in cell number}

The cell count increased by 6-7 times the original concentration in the case of normal yeasts (UD and LM) but only 3-4 times in the case of RDM yeast (UDm4). In all fermentations, the cell growth reached near-stationary phase after 6-8 days of fermentation (Figure 7). The graphs show considerable lag time for growth, which is in contrast to commercial yeast fermentation. This could be due to the inherent property of the feral yeast used in this study. Using this presumptive data as the guideline, a confirmatory study can be carried out for detailed kinetic studies.

The mutant yeast did not appear to respond well, vis-à-vis cell multiplication. This is explicable because the mutants have lost the ability to respire glucose, a property of the RDMs (Bacila et al, 1978; Hammond, 2003).

\section{Alcohol yield}

Udm4, UD and LM were found to produce 13.3, 12.2 and
$11.65 \%$ alcohol by volume (abv) from molasses media of $30^{\circ} \mathrm{Bx}$. The values are significantly different $(\mathrm{p}<0.05)$, the sequence in the decreasing order being UDm $4>\mathrm{UD}>\mathrm{LM}$. The significant enhancement in ethanol yield by UDm4 yeast ( $\sim 9 \%$ compared to UD and $\sim 16.5 \%$ compared to LM) can be explained on the basis of work done by Bacila et al (1978) and Hammond (2003). The authors mention that rho-negative $(\rho)$ yeast cells (mutants that have undergone sub-lethal mutation in mitochondrial DNA thereby resulting in RDMs that lack many components of the electron transport chain) are committed to ethanol production because they cannot respire glucose: because of the failing respiratory mechanisms, the $\rho^{-}$RDMs resort to enhanced ethanol production as a means to derive energy. The enhanced production of ethanol in spite of low cell count (growth) follows the same logic. The metabolite production is only partially growth-associated.

\section{Conslusions}

Subjecting murcha to molasses enrichment medium for a week or two results in strains of Saccharomyces cerevisiae as the dominant yeast. At UV radiation intensity of 44.21 $\mathrm{Wm}^{-2}(\lambda=254 \mathrm{~nm})$ with an exposure time of 20-25 s (plates seeded with feral yeast from murcha cakes) can yield 8-
$12 \%$ cell survival. RDMs comprise less than $1 / 4^{\text {th }}(\sim 22 \%)$ of the UV-survived colonies, with even small number acquiring the property for enhanced ethanol production. Feral yeasts from murcha can be UV-mutated to increase ethanol yield.

\section{References}

Atala DIP, Costa AC, Maciel R and Maugeri F. Kinetics of ethanol fermentation with high biomass concentration considering the effect of temperature. Applied Biochem. Biotechnol. 2001, 91-3, 353-365.

Bacila M, Xavier AW and Horii J. Induction of respiratorydeficient mutants of Saccharomyces and evaluation of their efficiency for ethanol production. In: "Biochemistry and Genetics of Yeasts: Pure and Applied Aspects". (Bacila M, Horecker BL and Stoppani AM, Eds.). 1978, 557-92. New York. Academic Press.

Boulton C and Quain D. Brewing Yeast and Fermentation. Blackwell Sci. Ltd. Oxford, U.K. 2001

Bridges BA. Mutation induction. In: "Second International Symposium and Genetics of Industrial Microbiology". (K. D. MacDonald, Ed.). 1976pp. 7 14, New York, Academic press.

Chambers PJ, Bellon JR, Schmidt SA, Varela C and Pretorius IS. Non-genetic engineering approaches for isolating and generating novel yeasts for industrial appliccations. In: "Yeast Biotechnology; Diversity and Applications". (T. Satyanarayana and G. Kunze, Eds). 2009, 437 New York. Springer.

D'Costa AR and Santoro I. The effect of UV radiation on the survival of yeast and its implications to a real-life situation. In: "Tested Studies for Laboratory Teaching" (Vol. 30). (K. L. Clase, Ed.). pp2009, 37182, Atlanta. Association for Biology Laboratory Education (ABLE).

Felix E, Clara O and Vincent AO. A kinetic study of the fermentation of cane sugar using Saccharomyces cerevisiae. Open J Phys Chem, 2014, 4, 26-31.

Hammond JRM. Yeast genetics. In: "Brewing Microbiology" (3rd ed.). (F. G. Priest and I. Campbell, Eds.). 2003, 71-8. New York. Springer Science.

Harrigan WF and McCance ME. Laboratory Methods in Food and Dairy Microbiology. Academic Press, London, 1976.

KC JB, Subba DK and Rai BK. Isolation of fermentative yeasts from some plants. Tribhuvan Univ. J, 1999, 22(2), 37-40.

Kurtzman CP, Boekhout T, Robert V, Fell JW and Deak T. Methods to identify yeasts. In: "Yeasts in Food: Beneficial and Detrimental Aspects". (T. Boekhout and V. Robert, Eds), pp., England, Woodland Publishing Limited, 2003, 69-72.

Lee CH. Cereal fermentations in countries of the Asia- 
Pacific region. In: "Fermented Cereals: A Global Reed G. Production of bakers' yeast. In: "Prescott and Perspective" Rome. FAO, (Vol. 138). (VT di Caracalla, Ed) 1999, 53.

Markert CL. Lethal and mutagenic effects of ultraviolet radiation of Glomerella conidia. Exp. Cell Res, 1953, 5(2), 427-35. Dunn's Industrial Microbiology" (4th ed.). (G. Reed, Ed), CBS Publishers and Distributors, Delhi, 1987, 594-6..

Reed G and Nagodawithana TW. Yeast Technology (2nd ed) Van Nostrand Reinhold, New York, 1991.

McCann AK and Barnett J. Starch utilization by yeasts: mutants resistant of carbon catabolite repression. Current Genetics 1984, 8, 525-30.

McKay M, Buglass AJ and Lee CG. Fermented beverages: beers, ciders, wines and related drinks. In: "Handbook of Alcoholic Beverages: Technical, Analytical and Nutritional Aspects" (Vol I), (A J Buglass Ed), 2011,77. UK John Wiley \& Sons Ltd.

Payne R W, Kurtzman CP and Fell JW. Key to species. In. "The Yeasts, A Taxonomic Study" (4th ed, revised and enlarged). (C. P. Kurtzman and J. W. Fell, Eds), Amsterdam. Elsevier, 1998, 940.

Rai BK. Preparation of starter culture using yeasts and molds isolated from local murcha. M.Tech (Food) Thesis, Tribhuvan Univ, Nepal, 2006.

Rai BK and Subba DK. Modified auxanogram for sugar substrates. J Inst Sci Technol, 2004, 13, 1-6.

Rai BK and Subba DK. Basic Practical Manual on Industrial Microbiology (1st ed) Lulu Publication. Smith JS and Burke DJ. Yeast Genetics: Methods and Protocols. Humana Press, USA, 2014.

Steensels J, Snoek T, Meersman E, Nicolino MP, Voordeckers $\mathrm{K}$ and Verstrepen KJ. Improving industrial yeast strains: exploiting natural and artificial diversity. FEMS Microbiol Rev, 2014, 38, 947-95.

von Borstel RC and Mehta RD. Mutation and selection systems for yeast. In: "Microbiology". (D. Schlessinger, Ed) pp, Washington DC, American Society of Microbiology, 1976, 507-9.

Walker, GM. Yeast Physiology and Biotechnology. John Wiley \& Sons Ltd, New York, 1998.

White $\mathrm{C}$ and Zainasheff J. Yeast: The Practical Guide to Beer Fermentation. Brewers Association, USA, 2010.

Winston F. EMS and UV mutagenesis in yeast. Current Protocols in Mol Biol, 2008, 13.3B. USA, 2016. 